\title{
The EU Accession to the Geneva Convention Relating to the Status of Refugees: Legal Feasibility and Added Value
}

\author{
Paula GIRCÍ I I IDR IDE:
}

\begin{abstract}
4bstract: The Stockholm Programme establishing the political priorities of the area of freedom, security and justice for the period 2010-201/4 stated that the EU should seek accession to the 1959 Geneva Convention on the status of refugees and its rg 67 Protocol. In spite of the political difficulties that the materialization of this recommendation, repeated in 2ont, would encounter, this contribution analyzes the legal implications of a hypothetical accession of the Union to the cornerstone of the internat ional regime on refuge protection, which simultaneously constitute the core of the EU asylum acquis by the direct reference found in art. 78. TFEU and art. I8 of the EU Charter of Fundamental Rights. For that purpose, this research firstly concentrates on analyzing the legal feasibility of the accession, both under EU law - focusing on the competence question, looking at its existence and also its nature with regard to Member States’powers_, and under international law —examining the terms of the Geneva Convention to identify the need for its revision or adjustment- Secondly, the added value of the accession is assessed, particularly regarding the current and future role and place the Geneva Convention enjoys within the EU legal order.
\end{abstract}

Kevwords: Geneva Convention on the status of refugees - EU accession - external competences - international agreements - refugee protection - ECJ jurisdiction

\section{(1) INTRODUCTIO)}

EU primary law accords to the 195. Geneva Convention relating to the Status of Refugees' (hereinafter, the 'RC') a central place in the making and implementation of the common asylum policy, since art. 78 TFEU requires this policy to be in accordance with the Geneva Convention of 28 July 195 and the Protocol of 3 I January 1967 relating to the status of refugees, and other relevant treaties'. The EU Charter of Fundamental Rights also ascertains, in art. 18, that 'the right to asylum shall be guaranteed with due respect for the rules of the Geneva Convention of 28 July 195 and the Protocol of 3 I January rg67 relating to the status of refugees and in accordance with the Treaty on European Union and the Treaty on the Functioning of the European Union'. Following this obligation, ${ }^{2}$ secondary law acts on asylum explicitly reaffirm that the RC constitutes the cornerstone of the Common European Asylum System (CE AS), ${ }^{3}$ and

a tricle published on.31 December 2019

Associate Professor of European Union Law, Universidad Pontificia Comillas (ICADE), Madrid. Mail: pgandrade $a$ icade.comillas.edu. This Chapter was written within the context of the research project 'The European Union's policies on asy lum: confluences between the internal and the external dimensions' (DER-2017-82966-R), funded by the Spanish Ministry of Economy and Compelitiveness and FEDER, as well as the Jean Monnet Chair EU Economic and Legal Integration for People, E AC/ $\mathrm{Aog}_{2016(2017-2020) .}$

U NTSS Vo. 2 亿行, vol. 189 , p. 137 .

2 Recalled in the five-vear programmes for the AFSJ adopted by the European Council: Tampere Conclusions, 15 ı6

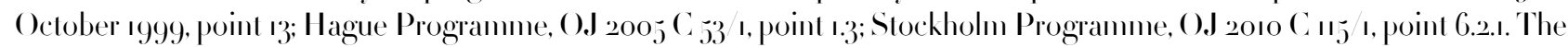
Strategic Guidelines for JII I (European Council Conclusions, 26 27 June 20r/p) contain however no reference to the RC.

3 See, e.g., reference in recital 4 of the preamble to Directive 2on 9. EU of the European Parliament and of the Council of 13 December 2011 on standards for the qualification of third-comntry nationals or stateless persons as beneficiaries of 
to that effect the EC.J has recalled, in several occasions, that EU asslum acquis must be interpreted in conformits with the Convention.'

In December 2009, the Stockholm Programme recalled the importance of a full and inclusive application of the RC as a basis of the EU asylum acquis, and clearly stated that "subject to a report from the Commission on the legal and practical consequences, the Union should seek accession to the Geneva Convention and its ig 67 Protocol's Two years later, in October 201 , the Council adopted a declaration by the EU on the occasion of the 6o ${ }^{\text {th }}$ anniversary of the RC, in which it called, as it usually does, on all countries that have not vet done so to accede to the RC and the New York Protocol and on those which have made geographical limitations and other reservations to reconsider these. "That Declaration additionally highlighted the advice included in the Stockholm Programme regarding EU's own accession to the RC.

EU accession to the Geneva Convention may encounter significant legal obstacles and come up against important political difficulties, so important that this objective might be qualified as unfeasible, unrealistic or utopian. However, the truth is that there is an indication or recommendation to accede to this international convention, which has been made by the European Council, composed by the Heads of State and Government of the EU Member States, and the Council, entrusted with political decisionmaking power in the Union. The political relevance of the institutions who authored the advice therefore requires a legal analysis on the feasibility of that accession. At a time in which the EU is so enthusiastically showing its commitment to strengthen the international refugee protection regime by its contribution and adoption of the Global Compact on Refugees, ${ }^{7}$ also demonstrating the increasing importance attached to soft law instruments in this global governance regime, it seems a good moment to revisit this topic and to determine whether the Union could be directly bound by the most relevant legally-binding international instrument in this field. To that effect, this contribution will firstly concentrate on analysing the legal feasibility of the accession, both under EU law — focusing on the competence question — and under international law — examining the terms of the RC for this purpose—. In a second part, the added value of the accession, particularly regarding the current and future role and place the RC enjoys within EU law, will be assessed.

\section{(B) TIIELEGILFEASIBILITY OF TIIEEU ACCESSION TOTIIE REFU GEECONDE\TIO}

\footnotetext{
international protection, for a uniform status for refugees or for persons eligible for subsidiary protection, and for the content of the protection granted, O.J 2011 L 337 9.

4 See, among others, judgment of 2 March 2010, Abdulla, joined Cases C-175 o8, C-176/o8, C-178/o8 and C-179 o8, EU:C:2010:105, paras. $5^{1-}-53$.

5 Point 6.2.1, p. 6g. The Commission’' 'Action Plan Implementing the Stockholm Programme'(COM (2010)171, 20.1.2010) fived 2013 as deadline for submitling this report, which, to our knowledge, has not been adopted vet.

6. JII A Council, 'European Union Declaration on the Goth Anniversary of the 1959 Convention Relating to the Status of Refugees, $27-280$ october 2011, p. 2.

7 Global Compact on Refugees, Report of U NIICR, Part II, I/73/12, affirmed by the U VG I in its resolution of 17 December 2018 .
} 
(I) Under EU law: the competence question

Analysing the feasibility of EU accession to the RC under an EU law perspective must concentrate on the essential legal question of competences. Iaving the general capacity to conclude international agreements, we should determine whether the EU enjoys a specific external competence to ratify this Convention (a). In the affirmative, we will assess whether that competences is currently exclusive to the Union and thus would allow it to replace its Member States as parties to the RC, or shared with the treatymaking power of Member States (b).

\section{(a) The exislence of an EU exlernal compelence on asylum}

According to art. 2I6.I TFEU, the Union may conclude an international agreement when an explicit external competence has been conferred upon it by the Treaties, or where the conclusion of that agreement is necessary to achieve one of the objectives for which the Union has been attributed a corresponding internal competence.

The Lisbon reform added a new legal basis in art. 78.2 (g) TFEU, by which the European Parliament and the Council shall adopt measures for a common European asylum system comprising partnership and cooperation with third countries for the purpose of managing inflows of people applying for asylum or subsidiary or temporary protection'. Some authors have interpreted this reference to cooperation with third countries as an attribution to the EU of an explicit external competence on asylum. ${ }^{9}$ However, in my view, art. 78.2 TFEU specifically refers to an internal competence, ${ }^{10}$ from which we could deduce an implied external competence, following the EC.J doctrine codified in art. 216.r TFEU." Moreover, the objective to be achieved by this legal basis is quite specific. Instead of a broad recognition of the external dimension of the EU asylum policy, this provision aims at facilitating cooperation with third countries "in order to manage inflows of people applying for international protection and it would therefore constitute the adequate legal basis for an EU act regulating some form of extrateritorial management of asylum

"The Union may conclude an agreement with one or more third countries or international organisations where the Treaties so provide or where the conclusion of an agreement is necessary in order to achieve, within the framework of the Union's policies, one of the objectives referred to in the Treaties, or is provided for in a legally binding Union act or is likely to affect common rules or alter their scope'(emphasis added). The third ground of attribution referred to in this provision appears to be an incorrect codification of ERT A case-law, which relates to the exclusivity and thus the nature of the EU external competences, and not to their existence. For an in-depth analysis of the system of distribution of external competences, see, among others, P. Eeckout, EU Exlernal Relations Law (2nd ed., Oxford U niversity Press, 20I2), at II-I8g. We have analyzed this system and its application to the migration domains in P. García Andrade, 'EU external competences in the field of migration: how to act externally when thinking internally', „5. CMLR (2018), 157-200.

9 See, e.g., K. Mailbronner and I). Thym, EU Immigration and 1sylum Law. A Commenlary (2nd ed., Beck I Iart/ Tomos, 201(6), at 10/9.

1) In this sense, see G. De Baere, The basies of EU external relations law: In overview of the post-Lisbon constitutional framework for developing the external dimension of EU asylum and migration policy, in Maes, Foblets and De Bruycker (eds.), Exlernal Dimension of European Vigration Law and Policy (Bruylant, 2011), at i68.

" It could even be argued that the terms employed in art. $78.2 \mathrm{~g}$ ) TFEU point at an objective, which has been transformed into an internal competence. 
seekers.'. This provision cannot therefore be the basis for an EU external competence - neither explicit nor implied_to accede to the RC.

It is then necessary to determine whether we can infer from other Treaty provisions an implied external competence enabling the Union to accede to the RC. For this purpose, a clarification on the aims and scope of this international treaty is firstly required. The RC, as the centrepiece of the international legal framework of refugee protection, is a status and rights-based instrument. ${ }^{33}$ It covers thus the definition of refugee and the legal status of those who qualify as refugees. Since a person is a refugee the moment she fulfills the refugee definition, refugee status being declaratory, asy lum seekers pertain to the Convention categories of refugees 'present in the territory' or "law fully present'.' This means that the scope of the RCalso extends to the rights and reception conditions granted to asylum seekers.

Given the material scope of the Geneva Convention as an instrument addressing the qualification to be a refugee, the needs of protection seekers and thus secondary rights conforming the status of refugees, the most correct legal basis in EU primary law for the EU accession to the RC would be, in my view, to derive an implied external competence from certain Treaty provisions on a common policy on asylum, more particularly art. 78.2 (a) and (f) TFEU. These provisions confer an internal competence to the Union to regulate 'a uniform status of asylum for nationals of third countries'and the standards concerning the conditions for the reception of applicants for asylum', respectively. Following the EC.J doctrine on implied external competences codified in art. $216 . \mathrm{TFEU}$, the existence of an implicit external competence in a specific field requires that the conclusion of an international agreement by the Union facilitates the achievement of the objectives for which it has been attributed an internal competence ${ }^{5}$. It could be easily argued that acceding to the RC would facilitate the achievement by the EU of the objectives of these internal competences, which are offering appropriate status to any third-country national requiring international protection and ensuring compliance with the principle of non-refoulemeni, as stated in art. 78.1 TFEU.

It seems important to note for this purpose that the RC does not contain procedural rules for determining who is a refugee. This means that, although EU secondary law on asylum procedures must of course be in compliance with the RC, most notably with the principle of non-refoulment, the scope of application of the Convention is not related to the EU internal competence, enshrined in art. 78.2 (d) TFEU,

12 As Teitgen-Colly indicates, this provision 'confirms the persistent confusion between the requirements of asv lum, which concern protection, and the requirements of management of migration flows, which concern their control and management:

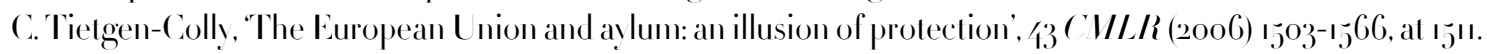

3 Introductory Vote by the U NIICR to the Geneva Convention, 2010, p. 3.

'1 RC rights pertaining to refugees law fully staving are accessible only to refugees to who ass lum has been granted in the EU: E. Tsourdi, 'EU Reception Conditions: A Dignified Standard of Living for Asslum Seekers?', in V. Chetail, P. De Bruycker and F. Maiani (eds.), Reforming the Common European Asvlum System. The New European Refugee Law (Brill/ Nijhofl, Leiden, 2016), at 27 .

15. Judgments of 31 March 197ı, 22 70, Commission v. Council (ERT 1), EU:C:1971:32, para ı6; 1/4 July 1976, joined cases 3, 4 \& 6 76, Kramer, EU:C:1976:11, paras. 20 and 3o; Opinion i 76, Laying-up Fund, EU:C:1977:63, para 3 . See García Andrade, supra n. 8, al ו6ı-ı62. 
to establish "common procedures for the granting and withdrawing of uniform asylum or subsidiary protection status'.

Finally, it could be adequate to make a comparison with the EU accession to the European Convention for the Protection of Ituman Rights and Fundamental Freedoms (hereinafter, the ECIIR), for which an explicit and specific external competence has been provided in art. 6.2 TEU. This conferral has been operated by the Lisbon reform in response to the EC.J stating, in Opinion 2/94, that the Community was not competent to accede to the ECIIR, as it lacked the power to legislate on human rights or to conclude international conventions in this field. ${ }^{77}$ It could indeed be argued that, in the absence of an explicit provision similar to art. 6.2 TEU, the EU would not be allowed to accede to the RC in the current state of EU primary law, as this Convention is clearly an instrument of human rights protection. The situation would not be however the same. Contrary to a lack of a general normative competence to enact rules on the protection of human rights, ${ }^{8}$ the Union is competent to establish a common policy on asy lum according to art. 78 TFEU, and more particularly to legislate on the status of asylum, including thus the qualification for being a refugee and the content of rights associated to it.

\section{(b) The nalure of EU exlernal compelences on asylum}

Once we have affirmed to the existence of an implied external competence, deduced from art. 78.2 (a) and (f) TFEU, which would allow the Union to accede to the RC, it is necessary to examine the nature of that competence and thus whether this power should be qualified as exclusive or shared with Member States.

Art. 1.2 (j) TFEU qualifies the AFSJ as a field of shared competence, therefore excluding an a priori exclusive external competence of the $\mathbf{E U}$ on asylum. ${ }^{19}$ Nonetheless, does the Union enjoy an exclusive external competence based on the principle of pre-emption and grounded on preventing the affectation of existing EU common rules on asy lum? Indeed, ERT A exclusivity, codified in art. 3.2 TFEU, ${ }^{20}$ is founded on the principle that, where common rules have been adopted by the Union, Member States no longer have the power to undertake international obligations which may affect the uniform application of those common rules, having thus the Union the exclusive competence to assume those international commitments.

16. The Union shall accede to the European Convention for the Protection of Ituman Rights and Fundamental Freedoms. Such accession shall not affect the Union's competences as defined in the Treaties'.

17 Opinion of 28 March 1996, 2/9, EU:C:1996:1/40, para. 27: "No Treaty provision confers on the Community institutions any general power to enact rules on human rights or to conclude international conventions in this field'. The flexibility clause of art. $33^{2}$ TFEU was also ruled out by the Court (paras. $33^{2-3} 3^{6)}$.

is Art. 6 TEU recalls wice that neither the EU Charter of Fundamental Rights nor the future EU accession to the ECIIR would extend or affect the Union's competences as defined in the Treaties.

19 The Union has a priori exclusive competences in the policy fields listed in art. 3.. TFEU.

${ }_{20}$ To codify the complex case-law of the EC.J on external competences, art. 3.2 TFEU states that the Union shall be exclusively competent to conclude an international agreement when its conclusion is provided for in a legislative act of the Union or is necessary to enable the U nion to exercise its internal competence, or in so far as its conclusion may affect common rules or alter their scope. The third scenario enshrines ERT A exclusivity. However, the first one is rather an indication of ERT I exclusivity, while the second refers to the ECJ doctrine of Opinion a 76 , based on the indispensable character of the EU external competence to achieve the objectives of one of its internal competences. For a detailed analysis, see García Andrade, supra $\mathrm{n}$. 8 , al $165 \mathrm{el} \mathrm{seq}$. 
Is the Court required in its Opinion a o3, this finding derives from a comprehensive and detailed analysis'of the relationship between the potential envisaged agreement and existing Union rules in that field, ${ }^{21}$ first comparing the areas covered by both types of rules, without it being necessary that they coincide fully. ${ }^{22}$ On the contrary, it is sufficient that the area is already covered to a large extent by (Union) rules.'3 The Court also highlighted that determining whether the EU enjoys an ERTA competence to conclude an international agreement must take into account not only the scope of the rules, but also their nature and content in order to ensure that the agreement is not able to undermine the uniform application of EU secondary law. ${ }^{2}$ In that regard, the fact that both the Community rules and the international agreement lay down minimum standards may justify the conclusion that the Community rules are not affected, even if the Community rules and the provisions of the agreement cover the same area.2.5

When analysing the level of harmonization achieved by Directive 2011/95, the 'Qualification Directive'(hereinafter QD), ${ }^{26}$ and Directive 2013/33, the 'Reception Conditions Directive'(hereinafter RCD), ${ }^{27}$ we have to firstly take a look back to the requirements established in EU primary law for the adoption of the instruments of the first phase of the asylum legislation package. Art. 63 TEC requested that all asylum measures to be adopted by EU institutions were to set 'minimum standards, ${ }^{28}$ enjoining the EU legislature to leave sufficient margin of discretion to Member States in order to adopt more favourable standards. This requirement, as can be observed in Directive $200 / 483^{29}$ and Directive $20039,3^{30}$ which referred to 'minimum standards'even in their titles, indeed compromised the harmonization process from its inception'and "paved the way for a 'race to the bottom'harmonization' ${ }^{31}$ In addition to the principle of 'minimum standards', the resulting directives were full of references to national law, optional clauses, exemptions, ambiguities, contradictions and other 'loophole techniques'?23 The need for legislative reform

2 Opinion a o3, Lugano Convention, EU:C:2006:8ı, para. 133.

22 Ibid, paras. 12/-12

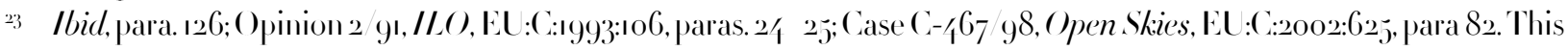
broad interpretation of the ERTA principle was confirmed in Case C-11/12, Commission v. Council (Broadcasting Rights),

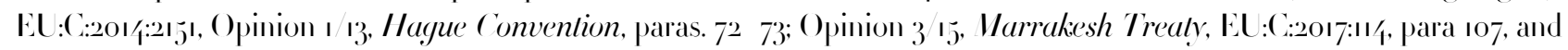

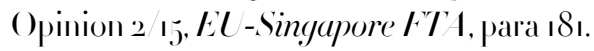

2 Opinion I/03, para. 126.

25 Ibid, para. 127 .

26. See notezsupra.

${ }_{27}$ Directive 201333 EU of the European Parliament and of the Council of 26 June 2013 laying down standards for the reception of applicants for international protection, O.J L I80, 29.6.2013. P. $9^{6}$.

28 Except for the rules on the allocation of responsibility among Wember States to examining an asylum request (art. 63.I (a) TEC).

29 Council Directive $200 / 43$ EC of 29 April $200 / 4$ on minimum slandards for the qualification and status of third country nationals or stateless persons as refugees or as persons who otherwise need international protection and the content of the protection granted, O.J L $30 \%$, 30.9 .20 , p. p. 12.

$3^{\circ}$ Council Directive 2003 9 EC of 27 January 2003 laving down minimum standards for the reception of asvlum seekers, O.J L.3, 6.2.2003, p. I8.

${ }^{31} \quad$ V. Chetail, 'The Common European Asylum System: Bric-à-brac or System?', in V. Chetail, P. De Bruycker and F. Maiani (eds.), Reforming the Common European Asylum Syslem. The New European Refugee Law (Brill/ Nijhoff, Leiden, 2016), at 12.

$3^{2} \quad$ Teitgen-Colly, supra n. 12, at 1512-1513. 
of existing secondary law norms on asylum was clearly indispensable.33 The adoption of the second phase of asylum instruments has benefitted from certain reforms operated by the Lisbon Treaty regarding the asylum competences of the EU: most importantly, the explicit and legally-binding objective of creating a 'common European asy lum system"in art. $78(2)$ TFEU; 3 the extension of the ordinary legislative procedure to this field; and the suppression of the 'minimum standards'requirement for EU legislation on asylum. ${ }^{35}$ Under this new constitutional framework, the European Parliament and the Council adopted Directive $2011 / 95$ and Directive 2013 33, in which some positive improvements can be acknowledged, representing quite a noticeable progress compared to previous legislation. Itowever, the legislative reform has been quite modest and consisting in a reformulation and consolidation of the existing acquis rather than a real reform. ${ }^{6}$ Even if Directives 2011/95 and 201333 advance in establishing common provisions, exlending thus the level of harmonization, ${ }^{37}$ the QD and the RCD still allow Member States to adopt or retain more favourable slandards in national legistation ${ }^{3}{ }^{8}$, in so far as those standards are compatible with these Directives. ${ }^{39}$ Consequently, although the requirement for minimum standards in asylum legislation of former art. 63 ECT has been suppressed by the Lisbon reform, its effects are still visible in EU secondary law. ${ }^{\circ}$ Moreover, certain provisions of the QD and the RCD still contain optional clauses and leave margin of discretion to Member States.

Vote to this effect that the 'minimum standards'characteristic of Union rules must be shared by the rules of the envisaged agreement for the purpose of excluding affectation in the sense of the ERT I

33 See the assessment by the Commission of these first phase legislative instruments of the CEAS in its 'Policy Plan on Asylum: An Integrated Approach to Protection Across the EU, COM (2008) 360, 17 June 2008.

3 Emphasis added.

35 Art. 78 (2) TFUE refers to 'uniform'status of asylum and subsidiary protection, to a 'common'system of temporary protection and to "common procedures for the granting and withdrawing of asylum or subsidiary protection status. The standards concerning reception conditions for asylum or subsidiary protection applicants were not however qualified (simply 'standards'), but indeed the adjective 'minimaliwas suppressed in that regard too.

$3^{6}$ Chelail, supra $\mathrm{n} .3 \mathrm{3}$, at 27.

37 Tsourdi claims that the level of harmonization in Directive 201333 is higher than that of Directive 2003 9, but still contains exceptional clauses, vague notions allowing for Member States'discretion and internal contradictions: Tsourdi, supra n. I/, at 3ro. For similar views on the QD), see II. Batljes, 'Piecemeal Engineering: The Recast of the Rules on Qualification for International Protection', in V.Chetail, P. De Bruycker and F. Maiani (eds.), Reforming the Common European 1 sylum Syslem. The New European Refugee Law (Brill Nijhoff, Leiden, 2016) 197-239, and S. Peers, V. Moreno Lax, M. Garlick and E. Guild, 'Qualification: Refugee Status and Subsidiary Protection', in S. Peers el al, EU Immigralion and Asylum Law (Tex and Commentary): Second Revised Edition. Volume z: EU Asylum Law (Brill/ Vihjofl, 2015) 65-2ı.

$3^{8}$ See art. 3 of the QD and art. of the RCD.

39 As explicitly stated in the above-mentioned provisions. See judgment of 9 November $2010, B$ and D, C- 57 og and CIOI og, EU:C:2010:661, para. ${ }_{5}$, in which the Court interpreted art. 3 QD) in the sense that the power to adopt or retain more favourable national provisions must not overlook the need to maintain the credibility of the protection system provided for in the Directive in accordance with the RC. It must be recalled that art. 63, penultimate paragraph, TEC required the national provisions that Member States could maintain or introduce to be compatible with this Treaty and with international agreements'. On this question, see the arguments in II. Balljes, European Asvlum Law and Inlernalional Law (Martinus Vijhoff Publishers, 2006), at 202-203, and S. Peers, EU Justice and IIome Affairs Law. I olume I: EU Immigralion and Asylum Law (, the ed., Oxford U niversity Press, 2016), at 2/2.

(1) It is true that the objective of establishing a common European astum system and the suppression of the requirement for minimum standards in asy lum legislation 'supports extensive legislative activities and argues for a restrictive reading of the clauses on national deviations that compromise uniformity': K. Mailbronner and I). Thym, supra n. 9, at $\mathbf{r}_{5}$. 
doctrine. it Since art. 5 of the RC allows its Parties to grant additional rights and benefits to refugees, we may interpret that the 'envisaged agreement'also leaves a margin of discretion to EU Member States, ${ }^{2}$ confirming thus the exclusion of an ERT A exclusivity.

A further step in the analy sis is however necessary, as the Court also required in its ERT A doctrine to lake into account not only the current state of (Union) law in the area in question but also its future development, insofar as that is foreseeable at the lime of that analysis. This means we will have to take into account the proposal to replace the (QD) with a regulation, ${ }^{\prime \prime}$ and the proposal to amend the RCD,, both adopted by the Commission in July 2016 as part of the third phase of harmonization of the EU asylum acquis. This criterion on the 'future and foreseeable developments' of Union law should however, in my view, be interpreted cautiously in order to balance the objective of protecting the uniformity of 'future'EU

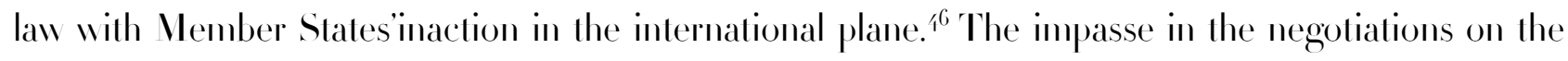
reform of the EU asylum acquis —especially concerning the Dublin Regulation and the Asylum Procedures Regulation proposals which are also part of the package- seems to reinforce this caution.

Finally, even if we could affirm to the exhaustive harmonization of Union rules in these fields, ${ }^{17} \mathbf{E U}$ Member States retain the sovereign power to examine an asylum request and the power to grant asylum in application of EU common rules. On the latter power, I do not think however it affects the determination of the nature of the Union external competence to adhere to the RC, as the Convention only endorses upon States Parties an obligation of non-refoulment, and not a right to asylum or duty on the part of States to admit refugees. ${ }^{8}$ The territorial power of States to grant asy lum - albeit no longer discretionary under EU law ${ }^{19}$ - would not therefore be an obstacle to a future EU exclusive external competence to adhere to the

i If onl Union rules are minimal, the conclusion of the agreement by Member States would prevent the EU from enhancing internal harmonization in the future in a stricter way than the rules of the agreement: Opinion $2 / 9$, para. I8; Opinion 1/03, paras. 123-127; Broadcasling Righls, para 91.

$i^{2}$ Although the original purpose of art. $j$ RC was to safeguard the privileges of particular refugee classes existing at the time of the entry into force of the Convention, its terms are to be interpreted as an encouragement to States to legislate domestically beyond the standards of the Refugee Convention and, particularly, in its insistence that state parties continue to accord refugees all advantages that accrue to them by virtue of other international agreements': J. C. Ilathaway, The Rights of Refugees under Inlernational Law (Cambridge U niversity Press, 2005), at 108-109.

1.3 Opinion s o3, para. 126.

任 Proposal for a Regulation of the European Parliament and of the Council on standards for the qualification of thirdcountry nationals or stateless persons as beneficiaries of international protection, for a uniform status for refugees or for persons eligible for subsidiary protection and for the content of the protection granted and amending Council Directive $2003 / 109$ EC of 25 Vovember 2003 concerning the status of third-country nationals who are long-term residents, COM (2016) 466, 13 Juls 2016.

4.5 Proposal for a Directive of the European Parliament and of the Council laving down standards for the reception of applicants for international protection (recast), COM (2016) $46_{5}, 13$ July 2016.

16. For a concrete example, see Case C-66/13, Green Velwork, EL:C:201/2:2399, paras. 63 6/1.

i7 For this view, see Hailbronner and Thym, supra n. 9, at to 6 6.

is Among abundant literature, see Mathaway, supra n. 12, at 3oo-3or; G.S. Goodwin-Gill and J. Mc Adam, The Refugee in Inlernational Law (3rd ed., Oxford University Press, 2007) at 362; M.-T. Gil-Bazo, 'Asylum as a General Principle of International Law', 27(1) Inlernational Journal of Refugee Law (2015) 3-28, at 9.

19 According to Gil-Bazo, the QD constitutes the first legally binding instrument of supranational character in Europe that imposes an obligation on states to grant asylum to persons who qualify as refugees: M.-T. Gil Bazo, 'Refugee status, subsidiary 
RC..$^{50}$ Vevertheless, on the former power, EU primary law still indicates that the examination of an asy lum application pertains to the responsibility of Member States, ${ }^{51}$ and this power is indeed covered by the RC. Consequently, if the level of harmonization of Union rules on asylum increases up to the point of making possible to qualify these as 'common rules', the Union would not be able to replace Member States as parties to the RC.

In case of accession, Member States would continue to be parties to the Convention in their own right. A declaration of competences would be nevertheless required to the Union in order to clarify to other parties to the RC the distribution of competences with regard to its Member States, and thus make the delimitation of international responsibility clearer. This conclusion means that the RC would have the status of a mixed agreement within the EU legal order, the implications of which will be considered in section Cibelow.

In case political will favoured accession, it would be highly recommended to seek an opinion from the EC.J under its consultative competence enshrined in art. $218 . n$ TFEU, in order to ensure the compatibility of the accession with EU law..$^{2}$ A priori, the EU acquis on asylum should be compliant with the RC, as this is an explicit requirement of primary law. In that regard, apart from the contradictions or cases in which EU legislation may be at odds with the RC, ${ }^{33}$ a point of conflict to arise could be Protocol 24 on asy lum for nationals of Member States of the European Union (the so-called 'Aznar Protocol'). This Protocol to the EU Treaties is considered to be in contradiction to the RC, and more particularly to art. I and $3^{5,5}$ since being national of a Member State cannot be assimilated to any of the exclusion clauses foreseen in the former and the latter forbids discrimination on the basis of refugees'country of origin. ${ }^{53}$ Some legal

protection, and the right to be granted asslum under EC law', U NIICR, New Issues in Refugee, Research Paper no. 136, 1-30. To this effect, see art. 13 of Directive 2011/95, which binds Member States to grant refugee status to third-country nationals or stateless persons who qualify as refugees in accordance with chapters II and III of the Directive: Gil-Bazo; Teitgen-Colly, supra n. 12, at 1539. On the obligation under art. 2/ of the QD) to issue a residence permit leading to a subjective claim of territorial protection, see S. Peers, V. Moreno Lax, M. Garlick and E. Guild, supra n. 37, at n6.

$5^{\circ}$ It could also be argued that the regulation on issues such as education, freedom of religion, freedom of association, regime of property rights or housing remains in the hands of Member States: see P. De Bruycker el al, Selling up a Common

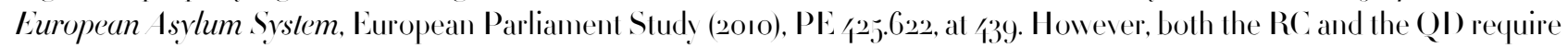
Nember States to grant similar rights to nationals or to other third-country nationals in these fields, excluding thus the involvement of their power to regulate these material fields.

${ }^{5} \quad$ Art. 78.2 (e) TFEU refers to the criteria and mechanisms for determining which Wember Slale is responsible for considering an application for asylum or subsidiary protection'. Emphasis added.

$5^{2}$ A possible argument against accession from a EU perspective would lie in a comparison to the EU accession to the ECIIR, to which the ECJ objected because of the substantial change that ECIIR accession would entail in the EU as a consequence of the supervision by the Strasbourg Court and the integration of ECIIR provisions into the EU legal order (Opinion 2 94, para. 34). The fact that accession to the RC does not entail entering into another institutional system and that RC provisions are already integrated to a large extent into EU law, there would not be a substantial change'argument to confront: Balljes, supra n. 39, al nole 6ı, p. 127.

33 See Batljes, supra n. 37 and n. 39; S. Peers, V. Moreno Lax, M. Garlick and E. Guild, supra n. 37.

3 Art. 彳2. Re forbids reservations to both articles.

5.5 See, among others, F. Julien-Laferrière, 'La compatibilité de la politique d'asile de l'Union européenne avec la Convention de Genève du 28 juillet 195̆ relative au Statut des Réfugiés', in V. Chetail (dir.), La Convention de Genève du 28 juillet 19.5I relative au Slatul des Réfugiés. jo ans après: bilan el perspectives (Brụ lant, Bruxelles, 2001), at 262-26/; J. Mc Adam, 'Regionalising International Refugee Law in the European Union: Democratic Revision or Revisionist Democracy?', ı 
scholars however argue that the cases contemplated in the Aznar Protocol, albeit containing a presumption for asylum requests by EU citizens to be manifestly unfounded, might be interpreted as not impairing access to examination procedures. ${ }^{-6}$ Votwithstanding, this incompatibility or contradiction already applies to EU Member States'commitments towards the RC, given that the Aznar Protocol has primary law value. On its impact on the accession issue, it has been argued that the EC.J could precisely find this incompatibility as an argument to deliver a negative opinion under art. 218.ı TFEU or the reason for third countries'opposition to EU accession, which could raise the need to look up for adjustments of EU primary law in this regard. ${ }^{57}$

(2) Under international law

Once the competence question under EU law has been clarified, it is lime to address the feasibility of an EU accession to the RCunder international law in order to determine whether there would be any obstacle to that accession from the perspective of the Convention itself and how to overcome it.

Firstly, the RC does not allow, at present, the accession by an international organisation. Art. 39:3 RC. states that the Convention is only open to "all States Members of the United Vations, and also on behalf of any other State invited to attend the Conference of Plenipotentiaries on the Status of Refugees and Stateless Persons or to which an invitation to sign will have been addressed by the General Assembly $5^{8}$ The same applies to the $1_{9} 67$ Protocol. ${ }^{99}$ This means that a hy pothetical EU accession to be realized would require amending these provisions, as it was done analogously when adjusting the ECIIR for allowing the accession by the EU.

Also, art. 38 RC confers settlement of disputes to the competence of the International Court of Justice, a jurisdiction before which the EU does not enjoy ius standi, neither to its contentious nor to its consultative competence. ${ }^{6 .}$ Other States parties to the RC might be precisely interested on that advantage of EU accession in order to be able to initiate proceedings in which the Union takes part. However, suffice to note in this regard that the IC.J has not received to date any action related to the interpretation or application of the RC.

I U II LawRw (2007). See also the criticism raised by U NIICR in U V IICR's Posilion on the Proposal of the European Council concerning the Trealment of Asvlum Ipplications from Citizens of European I nion Vember Stales, I Januarv r997, available at hllps: www.refworld.org docid/zac6b3ideb.html

$5^{6}$ See, e.g., Balljes, supra n. 39; or G. Noll, Negolialing Asvlum. The EU Acquis, Extralerrilorial Prolection and the Common Warkel of Deflection (Martinus Nijhoff, 2000), at $53^{6-557}$.

57 P. De Bruycker el al, supra n. jo, at 許1.

${ }_{5} 8 \mathrm{Art} 39.2 \mathrm{RC}$ to which a reference is made in art. $39.3 \mathrm{RC}$.

59) Art. V of the rg $_{7}$ Protocol also provides that accession is open to all States Parties to the RC, any other U Y Member State, anv member of anv of the specialized agencies or to which an invitation to accede mav have been addressed by the $\mathrm{U} \backslash \mathrm{V} \mathrm{V}$.

6o See Protocol no. I/ to the ECIIR (13 Mas 200/), which, in addition to amending the control sustem of the Convention, inserted a second paragraph in art. 59 stating that 'the European Union mav accede to this Convention'.

6. According to art. 34. of the Statute of the International Court of Justice, onls states mas be parties in cases before the Court', while art. 6.. in relation to art. 96 of the $\mathrm{C} \backslash$ Charter allows the General Assembly, the Security Council or to other $\mathrm{O}$ I organs or specialized agencies authorized by the General Assembly to request an advisory opinion of the IC.J. 
From an institutional perspective, the EU would be bound, in case of accession, to cooperate with U NICR on its duties, especially that of supervising the application of the RC, in accordance to art. 35 RC. This cooperation is already in place between the EU and U NIICR, ${ }^{{ }_{2}}$ but the latter's influence might increase. Vevertheless, current rules would not allow the Union to become part of the Execulive Committee of the U NICR, which is in charge of advising the Iligh Commissioner in the exercise of her functions, reviewing funds and programmes and authorizing the Iligh Commissioner to appeal for funds, as well as approve budget targets. Although the Committee does not have law-making competence, its conclusions are indicative of the consent of state parties to the GC. According to the U NIICR Statute, the Committee is composed of "representatives of States Members and States non-members of the United Vations', who are to be selected by the Economic and Social Council on the widest possible geographical basis from those States with a demonstrated interest in, and devotion to, the solution of the refugee problem. ${ }^{63}$ A revision of the E NICR Statute or the revision of the Convention itself could arrange for EU participation in that body. ${ }^{6}$ C Currently the EU has observer status on the ExCom, without right to vote or to oppose prevailing consensus on decisions to be adopted by the Committee. Its full status would imply the need for coordination with Member Statespositions, as the RC would correspond to a field of joint competences. If EU status in the Executive Committee could not be altered, the Union would be able to adopt a decision based on art. 218.9 TFEU determining its position regarding a specific decision of the Committee, position that Member States would have to present. ${ }^{6.5}$

The possibility and procedure to revise the RC is provided for in art. 仿 RC, according to which "any Contracting State may request revision of this Convention at any time by notification addressed to the Secretary-General of the United Vations'. A recommendation of the U VG I is required regarding the steps to be taken following that request. ${ }^{6.6}$ Consequently, a revision procedure of the RC aimed at allowing for EU accession could indeed be opened by any EU Member State and could merely imply the introduction of a generic reference to international organisations or a specific reference to the EU in art. 39 RC. Ilowever, a reform of the Convention might not be 'commendable because there is a risk to reopen a debate about its substance which could at the end be undermined'. ${ }^{6}{ }_{7}$ For this reason and because the

${ }_{62}$ Declaration iz to the Treaty of Amsterdam stated that consultations should be established with U VIICR and other international organisations in relation to asylum policy matters. U NICR has a bureau in Brussels in charge of developing this cooperation relationship with EU institutions and aimed at influencing negotiations of EU poliey and legislative proposals (see recent recommendations and comments in htlps: / www.unher.org working-with-the-european-institutions.html). In favour of reinforcing its role in the EU, see E. Guild and V. Moreno Las, Current challenges for inlernalional refugee law, wilh a focus on EU policies and EU co-operation with the U NIICR, Study, European Parliament, PE 133.7I, December 2013. On its relationship with the EC.J, the latter's Rules of Procedure do not allow for new third party interventions in a preliminary ruling, but only for those which were already parties to the national proceeding. For an assessment of the U VIICR intervention before the EC.J, see M. Garlick, 'International Protection in Court: The Asylum Jurisprudence of the Court of Justice of the EU and U VIICR', 3 彳 Refugee Surver Quarlerly (2015) 107-130.

${ }_{3}$ Art. , Statute of the Office of the U NIICR, General Assembly Resolution /28( ( ) of I/4 December 1950.

6, On its possitive effects, see P. De Bruycher el al, supra n. jo, at 行.

$6_{5}$ See judgment of 7 October 201/, OIV, C-399/12, EU:C:201/2:22 8 .

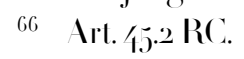

${ }_{6}{ }_{7}$ P. De Bruycker el al, supra n. jo, at j9. On the reform of the RC, see, e.g., "The Refugees Convention: whe not scrap it?", Summary of discussion at the International Law Programme Discussion Group at Chatham Ilouse, October 2005. 
amendment process would be cumbersome, slow and not likely to be completed with success, adapting the RC for EU accession could be solved by drafting a protocol to the Geneva Convention simply for this purpose, as the one used to arrange for the accession of the EU to the ECIIR as indicated above. This alternative would leave the text of the Convention intact, only focusing in the admission of the EU and thus preventing the opening of the Pandora box. ${ }^{68}$

Finally, attention should also be paid to the reservations the EU may make to the Convention at the time of accession, ${ }^{69}$ and particularly to the preservation of Member States'reservations to the RC $7^{70}$. As it has been suggested, a systematic examination of Member States'reservations should be done in order to ensure compatibility between the scope of national and EU commitments to the RC under this joint competence, and to check maintenance of these reservations in case of jurisdiction retained by the Member States. ${ }^{71}$

Although some legal adjustments are of course needed, especially at the international level, we may conclude to the legal feasibility of the EU acceding to the Geneva Convention. The next necessary question to address is whether a hy pothetical accession would provide for real added value both within the EU legal order and with regard to international law.

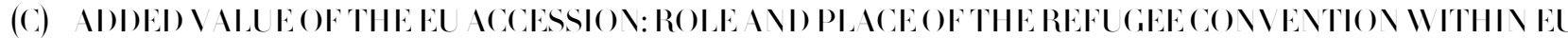

\section{LIII}

As recalled in the introduction above, the RCoccupies a central place in the designingand implementation of the common policy on asylum by virtue of the explicit reference made by EU primary law to the Convention itself. ${ }^{2}$ Firstly, it was the Maastricht Treaty which requested asylum and other JII A matters to be dealt in compliancewith the RC under the intergovernmental form of cooperation of the third pillar; ${ }^{73}$ later, the Amsterdam Treaty attributed to the EC the competence to adopt measures on asylum "in accordance with the Geneva Convention of 28 July $195^{1}$ and the Protocol of 31 January $1967^{\prime} ;{ }^{7}$ and finally the Lisbon reform recalled this obligation of compliance for the common policy on asylum, subsidiary protection and temporary protection? ${ }^{75}$ This explicit obligation to build a common policy that respects the

68 P. De Bruycker el al, supra n. jo, at 137. Hailbronner and Thym also refer to the option of a unilateral declaration by the EU to commit itself formally on the international plane to adhere to the Geneva Convention (I Iailbronner and Thym, supra $\mathrm{n}$. 9, at 10/6.

6. According to art. 彳 $^{2 .}$ RC, at the time of signature, ratification or accession, any State may make reservations to articles of the Convention other than to articles $1,3,4,16(\mathrm{I}), 33,3^{6-1} \mathbf{1}^{6}$ inclusive.

$7^{0}$ Most probably, Member States would insist on this preservation, as they have done regarding the EU accession to the ECIIR. See art. 2 of Protocol no. 8 to the EU Treaties relating to art. 6.2 TEU.

${ }^{7}$ P. De Bruycker el al, supra n. jo, at 439.

$7^{2}$ EU Treaties exclusivels refer to wo international treaties: the RC and the ECIIR.

33 Art. K.2, Treaty of Maastricht (1992).

74 Art. 73 K, Treaty of Amsterdam (1997). This reference was only inserted in art. 63.. TEC, and not regarding art. 63.2 TEC on the legal bases on temporary protection and balancing of efforts. On the implications of this limitation, see Batljes, supra $\mathrm{n}$. 39 , at $103-105$.

75 Art. 63.I, Treaty of Lisbon (2007). This reference, now in art. 78.1 TFEU, ends with the limitation mentioned above, as the whole common policy on asylum must be in accordance with the RC and the $g^{6} 7$ Protocol. 
RC clearly turns the Convention into a "central point of reference for the EU asylum acquis, ${ }^{7}{ }^{6}$ as well as a 'direct standard of decision'.77 The fundamental role of the RC in the EU legal order would be even superior' to that of the ECIIR, which is formally rather a source of legal knowledge for identifying general principles of EU law according to art. 6 TEU. In opposition, the RC becomes a source of law by virtue of primary (Union) law references to $\mathrm{it}^{7},^{8}$ only, of course, in the context of EU asylum law.

The essential role of the RC as constituting the cornerstone of the international legal regime for the protection of refugees is replicated in the EU legal order as erecting itself as the core of the EU asylum acquis. This can formally be observed in secondary legislation, which contain direct references to the RC.79 It is true that EU legislation might make multiple references to international instruments that the EU act in question must respect or conform with. Indeed, the obligations of Member States to respect their international commitments make necessary that EU legislation abide by those international treaties to which they are parties; otherwise, they would be placed under serious dilemmas on how to conform simultaneously to contradicting or incompatible obligations imposed by EU law, on the one hand, and international law, on the other. In those other cases however, the masters of the Treaties have not felt the need to include an explicit referral in EU primary law, as it is the case of art. 78 TFEU.

If we attempt to clarify the legal status the RC has at present in the EU legal order, it must be ascertained that all EU Member States are parties to the Convention. However, this does not mean that the Union has replaced or substitute for the Member States within the meaning of the succession criteria enshrined in EC.J case-law. ${ }^{80}$ According to the Court's doctrine, ${ }^{8}$ these criteria are the Member Stateswillingness to bind the EU to the international treaty and the acceptance of the EU by the other parties to the treaty. Whilst no indication can be found regarding the latter criterion, the willingness of Member States to bind the EU under the RC might be clear in light of the terms of art. 78 TFEU. Vevertheless, a complete transfer of powers to the EU regarding the scope of the RC has not been materialized, particularly in relation to the examination of asylum requests and thus the power to recognize a person as a refugee, ${ }^{8_{2}}$ which shows how Member States are not willing to have the EU taking over their full responsibilities under international law in this field.

$7^{6}$ Mailbronner and Thym, supra n. 9, at ıo, 6 .

77 R. Lerpmann, 'International Law as an Element of European Constitutional Law: International Supplementary Constitutions', in A. Ion Bogdand, European inlegration: the new German scholarship, Jean Monnet Morking Paper 9 o3 (2003), al 彳1.

78 Ibid.

79 To put only the (QI) as an example, it contains explicit references to the RC in recitals 3, 4, 1/, 22, 23, 2/, 29 and 33 of the preamble and in art. 2, 5, 9, 12, 1/, 20 and 2 5 . The Directive specifically states that standards for the definition and content of refugee status should be laid down to guide the competent national bodies of Member States in the application of the Geneva Convention'(recital 23 , preamble).

8o In this sense, see Ilailbronner and Thym, supra n. 9, at ı, 6 ; Balljes, supra n. 39, at 79-80; P. De Bruycher et al, supra n.

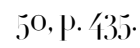

81 See Judgments of 12 December 1972, Inlernalional Fruil Company and olhers, joined cases 21 72 10 24 72, EU:C:1972:115, paras. 1/4- 18; of 3. June 2008, Inlerlanko and olhers, C-3o8 o6, EL:C:2008:312, paras. 12-19; and of 22 October 2oog, Bogialzi, C301 o8, EU:C:2009:6/9, paras. 2/-33.

82 In this sense, see Batljes, supra n. 39, at 80. 
Athough the EU is not therefore bound by the RC under international law for not being a party itself to the Convention, ${ }^{83}$ and since a succession to its Member Statesobligations under it cannot be ascertained either, the EU has however committed itself to respect the Convention under EU law. This certainly prevents a mismatch between the obligations of Member States under Union law and public international law, the EU legislature being obliged to adopt secondary law measures in conformity with the RC and the ECJ being bound to respect the Convention in the interpretation of the EU ass lum acquis. ${ }^{8}$ In case of conflict between Union rules and the RC, precedence is to be given to the latter, which means that EU secondary legislation can be annulled for breaching the RC in violation of art. 7 8. TFEU.

All EU Member States have ratified the RC before the Treaty of Amsterdam of 1997 transferred powers to the EU on astum, or before their accession to the EU, and thus the RC benefit from the protection of art. $35^{1}$ TFEU. ${ }^{85}$ The non-affectation of the rights and obligations arising for Member States

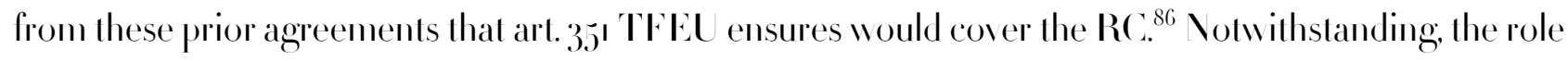
of the RC in the EU legal order and the protection granted to it could be said to be much stronger through the referral made in art. 78 TFEU, according to which we could even affirm that the RChas the same value as EU primary law. Art. 78 TFEU is thus qualified as lex specialis to art. $35^{1}$ TFEU as regards the legal effect of international refugee and human rights treaties. ${ }^{{ }_{7}}$ Following that argument, Batljes considers that, since the RC binds all Member States and is not in opposition to but reinforeed by EU primary law, the obligation of EU institutions not to impede performance by Member States of their obligations under international law ${ }^{88}$ becomes especially prominent. ${ }^{89}$ We may add that, as lex specialis, art. 78 TFEU

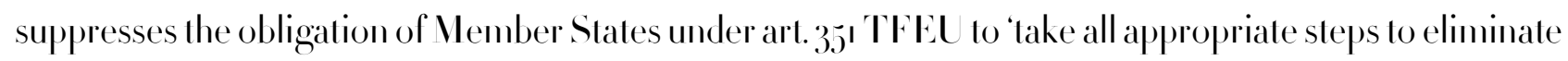
the incompatibilities established' by adjusting or denouncing its international commitments.

Would EU accession entail the RC to acquire a new status within EU law? If the EU becomes a party to the RC in its own right, the Convention would be transformed into conventional law of the EU. More particularly, the RC would have the status of a mixed agreement within EU law, as a treaty concluded by

83 It could be however argued that the Union is bound under international law by those RC provisions that can be qualified as customary international law rules, such as the prohibition of refoulement. See judgment of 2/ Vovember 1992, Poulsen, C286 9o, EU:C:1992:193, paras. 9-10; judgment of ı June 1998, Racke, C-ı62 96, EU:C:1998:293, paras. 行-46. In this sense, Balljes, supra n. 39, at $80-82$.

8, Mailbronner and Thym, supra n. 9, at 1029 and 10 /7.

85 Art. 351 TFUE gives precedence over EU law to the rights and obligations arising from international agreements concluded 'before s January 19.58 or, for acceding States, before the date of their accession'. However, it is understood that this protection applies from the moment in which the EU started to be competent on the field regulated under those agreements, that is, the entry into foree of the Amsterdam Treaty ( I May r999) with regard to ass lum issues. See Batljes, supra n. 39, at 6/4-6.

86 On art. 35. TFEU in general, see, among others, R. Schulze, 'EC Law and International Agreements of the Member States. An Ambivalent Relationship?", 9 Cambridge Yearbook of European Law Studies (2007), 337-140; J.-V. Louis, 'Les accords antérieures conclus par les États membres el le Droil Communautaire’, in Louis and Dony, Rélations Exlériures. Commentaire J. Mégrel, vol. 12 (Éd. U niversilé de Bruxelles, 200弓), $201-211$.

${ }_{7}$ S. Peers, 'I Iuman Rights, Asslum and European Community Law', 29(2) Refugee Surver Quarlerly (200/), al 29; Gil Bazo, supra n. 49 , at 5 .

88 Is affirmed in judgment of 1/4 October ig80, Burgoa, C-8I2 79, EU:C:1980:23ı, para. 9.

$8_{9}$ Balljes, supra n. 39, al 68. 
both the Union and its Member States.9. This would not alter the obligation by which EU legislation on asylum must abide by the RC, since EU secondary law is subordinated to those international conventions concluded by the Union and without prejudice to preserving the current drafting of art. 78 TFEU, which should not be altered because of accession.

Accession would certainly affect the jurisdiction of the ECJ with regard to the RC. In spite of the already high legal significance of its jurisprudence on the interpretation of the Convention at international level,9' the EC.J lacks competence to interpret the RC as a whole. Athough the Convention constitules a direct source of decision in accordance with art. 78 TFEU and, for that reason, determines the validity of EU legistation on asylum, ${ }^{92}$ the Court's jurisdiction to interpret the RC is not comprehensive, as underlined in Qurbani. ${ }^{93}$ In its response to this preliminary reference, the Court recalled to have jurisdiction to interpret international agreements concluded by the EU, but not on those international agreements concluded between Member States and third countries, ${ }^{91}$ the latter would only enter under the ECJ jurisdiction in case of succession. ${ }^{95}$ As this is not the case, the Court refused its jurisdiction to interpret direclly Article 3 , or any other article, of that convention, ${ }^{96}$ this finding not being called into question by references to the RC in art. 78 TFEU and art. 18 of the EU Charter. ${ }^{97}$ The Court concludes not to hold an autonomous jurisdiction to interpret the RC, but only in conjunction with secondary Union law. ${ }^{8}$ Consequently, the Court's competence will only extend to RC provisions, which have been reproduced by national law and by EU law — and that irrespective of the circumstances in which they are to apply and with the aim of forestalling future differences of interpretation- or to Convention provisions to which EU legislation makes a renvoi. ${ }^{99}$

The Court's jurisdiction would change with its status of agreement concluded by the EU, as no limitations would apply with regard to the kind of provisions that can be subject to its interpretation competence. The Court would be, after accession, competent to interpret the whole Convention as forming part of the EU legal order, ${ }^{100}$ irrespective of the distribution of competences between the Union and its Member States regarding the content of the Convention. The EC.J has already clarified in its case-

$9^{\circ} \quad$ On this issue, see P. García Andrade, 'EU external competences on migration: which role for mixed agreements?', in S. Carrera, J. Santos V ara and T. Strik (eds.), Constitutionalising the External Dimensions of EU Vigration Policies in Times of Crisis (Elgar, 2019) 39-56.

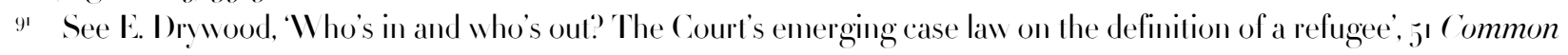
Markel Law Review (201/), 1093-112/, at 1095.

$9^{2}$ The integration of the RC into art. 78 TFEU makes the EC.J competent to also review in light of the RC. those Member States'acts which apply or implement EU asylum law. In this sense, see Batljes, supra n. 39, at 98-99. An additional basis for this control comes from the incorporation of the RC in art. I8 of the EU Charther.

93 In this sense, see Ilailbronner and Thym, supra n. 9, at 10 亿7.

91 Judgment of 17 July 201/, case C-481/3, Qurbani, EU:C:201/2101, para. 22.

95 Ibid, para. 23 .

$9^{6}$ Ibid, emphasis added.

97 Ibid, para. 2.

$9^{8} \quad$ Ilailbronner and Thym, supra n. 9, at 26.

99 Qurbani, paras. $26-28$.

100 Judgment of 3o April 1974, ILaegeman, 18 / 73, EU:C:1974:1, para. j. 
law that, in addition to its jurisdiction to define the obligations which the Union has assumed under an international agreement, the Court may interpret those provisions of an international agreement which can apply both to situations falling within the scope of national law and to situations falling within Union Law, in order to forestall future differences of interpretation. ${ }^{101}$ In that regard, the duty of close cooperation between EU institutions and Member States particularly applies when they are jointly parties to an international agreement. ${ }^{102}$ That would be the situation of the RC in case of EU accession. If that accession materialized without making a declaration of competences, both the EU and its Member States would assume with regard to other States Parties the whole of international commitments that the Convention contains, since the distribution of competences EU-Member States cannot be opposed to third countries. Who is responsible for the infringement of a provision of the RCwould therefore become an internal issue. For that purpose, the ECJ needs to be competent to interpret all the provisions of the Convention, even if some of these pertain to areas still in the hands of Member States. The extension of the ECJ jurisdiction over the whole provisions of the RC would consequently have relevant effects, especially in view of the increasing visibility the Court's position on the Convention has obtained in recent years at the international plane, ${ }^{103}$ and thus the potential it has to influence the development of international refugee law. ${ }^{10 /}$ The ECJ extension of jurisdiction may also increase normative coherence between the EU asylum acquis and international asylum law, ensuring thus greater consistency of the CE AS with the RC.

Additionally, we could put forward a legitimacy argument as an advantage of EU accession to the RC. On the one hand, it would increase the legal legitimacy of the EU legal order, which would be in an analogous situation to that of national legal orders of Member States. Nthough the RC lacks a specific international judicial body competent to address individual complaints, the EC.J will also see its legitimacy and authority on the interpretation and application of the Convention increased among EU Member States, even when they apply the Convention under national law. On the other hand, EU accession would lead to a clear extension of political legitimacy of the $\mathbf{E U}$ in the field of asylum, both ad intra with regard to its Member States, and especially ad extra, vis-à-vis third countries. ${ }^{105}$ The EU will become a full partner in the eyes of third countries, receiving an international recognition of the responsibilities its Member States have entrusted to it on asylum, a field in which the Union's credibility as international actor is particularly weak after its management of the so-called the refugee crisis of 2015 . As it has been argued

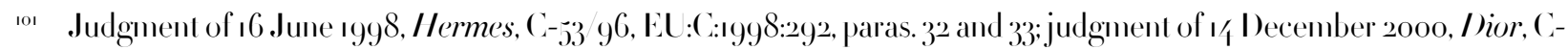

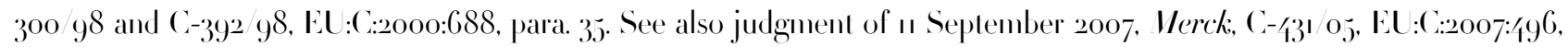
paras. $29-38$

${ }_{102}$ Ilermes, para. 36. See our analysis in P. García Andrade, The Duty of Cooperation in the External Dimension of the EU Migration Policy, in S. Carrera, L. den Ilertog, M. Panizzon and I). Kostakopoulou (eds.), EU Exlernal Vigralion Policies in an Era of Global Mobilities: Inlersecting Policy U niverses (Brill/ Vijhoff, 2019), 299-32̌.

103 Mailbronner and Thym also highlight the impact of EC.J judgments related to the RC on judicial practices worldwide (supra n. 9, at ı/8). According to Drywood, 'no international court has developed a jurisprudence on the interpretation of the Geneva Convention with the legal significance of that which is currently emanating from the EC.J': Drywood, supra n. 87, at 1095

10/ Drywood, supra n. 87, at I121-112/; M. Garlick, supra n. 62, at ıо7.

105 Uría applies these arguments to the EU accession to the ECIIR: E. L ría, La adhesión de la U nión Europea al Convenio Europeo de Derechos Ilumanos (Bosch, 2018). 
with regard to EU accession to ECIIR, human rights —as the rights of refugees are can only accomplish their mission and be credible if they can legitimize public actions that respect them and correct those that infringe them. ${ }^{106}$ The legitimacy of the EU urging countries to ratify the RC or to reconsider their reservations would certainly improve too. In sum, EU accession to the RC would therefore signal to its partners that it attempts to build an efficient CE IS without compromising but ensuring and even reinforcing its objective of refugee protection. ${ }^{107}$

\section{(I) CO\CLUDI\GREM IRKS}

This contribution has come to verify the legal feasibility of the European Union acceding to the RC, the core of the international refugee protection regime, as well as the fundamental pillar of the EU asylum acquis. On the basis of EU law, an implied external competence of the EU to conclude the RC can be affirmed. That competence would be shared with the powers of Member States, as the areas covered by the RC - the qualification of a refugee and the status of rights afforded to refugees and asylum seekers correspond to fields in which Union rules cannot be qualified as 'common' for the time being in the sense of ERTA exclusivity. A hypothetical accession by the EU to the RC would therefore preserve Member States as parties to the Convention, although their respective commitments under this international treaty would become intertwined. Under international law, the RC does not allow at present the accession by the EU or any other international organisation. Negotiating a protocol aimed at adapting the RC and the ${ }_{9} C_{7}$ Protocol to EU accession would be the recommended way forward, as a revision of the Convention itself would open a debate about its substance and would not ensure a successful ending.

EU accession to the RC would not constitute a mere cosmetic improvement but would present real added value. Nthough the RC already enjoys a prominent role within the EU legal order by incorporation through primary law, a new status of the Convention as an international agreement concluded by the EU and its Member States would extend the EC.J's jurisdiction to interpret its provisions, increasing even further the legal significance of its jurisprudence for influencing international refugee law. The impact on the political legitimacy of the EU, particularly ad extra, is not negligible either. The possibility that third countries might view the EU as a reliable international actor on refugee protection and not just as the face of burden-shifting with regard to global refugee challenges would increase its international credibility and enable it to really honour the values and principles in which the EU constitutional framework is founded. For that purpose however, a reconsideration by the Union and its Member States of some of the current political and legistative elements of the European asylum policy is certainly imperative.

106 See D. Sarmiento, 'EU fundamental rights as a source of integration or disintegration?', Despite our Differences Blog, April 2016, available at hltps: / despiteourdifferencesblog.wordpress.com/2016/0/10/eu-fundamental-rights-as-a-source-ofintegration-or-disintegration , and more particularly Uría, at ı $80-18$ ı.

${ }^{107}$ Vote that this would not be against EU objectives. Nlthough the CE IS had been originally created as a flanking measure of the abolition of internal border controls, the Lisbon treaty changed the objective to pursue by a common policy on asylum. The latter, as the common immigration policy, are no longer a spillover of the single market, but self-sufficient EU policies: Mailbronner and Thym, supra n. 9 , 
If EU institutions and Member States consider that the legal feasibility of EU accession to the RC is however impaired by political impracticality, they should probably think wwice before telling a jurist that this accession should be materialized. 